\title{
HUBUNGAN PERMAINAN OUTBOUND DENGAN PERKEMBANGAN SOSIAL ANAK DI TAMAN KANAK-KANAK KECAMATAN PADANGSIDIMPUAN UTARA
}

\author{
Rahmy Latifah ${ }^{1}$, Serli Marlina ${ }^{2}$ \\ Universitas Negeri Padang \\ e-mail: ${ }^{1}$ rahmy9971@gmail.com, ${ }^{2}$ serlimarlina@fip.unp.ac.id
}

Diterima: 7 November 2021 I Direvisi: 26 November 2021 I Disetujui: 27

November 2021 (C)2021 Pendidikan Guru Raudhatul Atfhal Fakultas Agama Islam Universitas Islam Malang

\begin{abstract}
Abstrak
Penelitian ini bertujuan untuk mengetahui hubungan permainan outbound dengan perkembangan sosial anak di Taman Kanak-kanak Kecamatan Padangsidimpuan Utara. Metode Penelitian yang digunakan adalah kuantitatif yang berbentuk korelasi dengan Teknik pengambilan sampel yaitu dengan cara gugus (cluster sampling). Hasil Penelitian terlihat bahwa terdapat hubungan antara permainan outbound dengan perkembangan sosial anak di Taman Kanak-kanak Kecamatan Padangsidimpuan Utara sebesar 84\%. Dapat disimpulkan bahwa permainan outbound memiliki hubungan terhadap perkembangan sosial anak.
\end{abstract}

Kata Kunci: Permainan Outbound; Perkembangan Sosial, Anak Taman Kanak-kanak

\begin{abstract}
This study aims to determine the relationship between outbound games and children's social development in Kindergarten Kecamatan Padangsidimpuan Utara. The research method used is quantitative in the form of correlation with the sampling technique, namely by cluster sampling. The results of the study show that there is a relationship between outbound games and children's social development in Kindergarten Kecamatan Padangsidimouan Utara by $85 \%$. It can be concluded that outbound games have a relationship with children's social development.
\end{abstract}

Keyword : Outbound Games; Social Development, Kindergarten Children

\section{A. Pendahuluan}

Anak usia dini adalah individu yang sedang mengalami proses pertumbuhan dan perkembangan yang sangat pesat, bahkan dikatakan sebagai lompatan

This work is licensed under Creative Commons Attribution Non Commercial 4.0 International License Available online on: http://riset.unisma.ac.id/index.php/fai/index 
perkembangan. Anak usia dini memiliki rentang usia yang sangat berharga dibanding usia-usia selanjutnya karena perkembangan kecerdasannya sangat luar biasa (Mulyasa, 2014:16).

Yusuf (2014:122) mengatakan perkembangan sosial adalah kedewasaan seseorang dalam berhubungan sosial. Perkembangan sosial juga berarti proses penyesuaian diri pada norma-norma kelompok, tradisi dan moral, serta saling berkomunikasi dan saling bekerja sama.

Ancok, 2006 : 2 dalam (Susari, 2016: 123) bermain dapat dilakukan dengan cara beraneka-ragam, salah satunya menggunakan strategi outbound atau belajar di alam terbuka. Outbound merupakan strategi belajar yang dilakukan di alam terbuka, penggunaannya dinilai memberikan kontribusi positif terhadap kesuksesan belajar anak.

Berdasarkan observasi yang dilakukan di Taman Kanak-kanak Kecamatan Padangsidimpuan Utara, menunjukkan bahwa perkembangan sosial anak di beberapa sekolah masih belum berkembang secara optimal. Hal tersebut dapat diketahui salah satunya pada saat anak melakukan kegiatan bermain balok, anakanak masih menunjukkan sikap tidak menghargai temannya, dan tanpa izin anak langsung mengambil mainan yang sedang dimainkan temannya, begitu juga dalam mencuci tangan, anak-anak tidak sabar dalam menunggu gilirannya.

Dengan begitu, permainan outbound dirasakan berhubungan dengan perkembangan sosial anak, karena permainan outbound sudah sangat tepat dalam mengembangkan ke-enam aspek perkembangan anak usia dini terutama pada perkembangan sosial anak. Apabila perkembangan sosial anak tidak berkembang secara optimal, akan mengakibatkan anak cenderung lebih pemalu, tidak mudah bergaul dan berkomunikasi dengan teman sebaya dan orang sekitarnya. Serta lebih fatalnya lagi akan mempengaruhi aspek perkembangan lainnya juga tidak akan berkembang secara optimal.

Oleh sebab itu sangatlah penting bagi pendidik dan juga orangtua untuk mengembangkan perkembangan sosial anak, dengan menggunakan permainan outbound secara tidak langsung kita dapat melatih anak agar terbiasa bersosialisasi terhadap teman sebaya, masyarakat ataupun orang lain yang berada di sekitarnya.

\section{B. Metode}

Berdasarkan permasalahan yang diteliti yaitu "Hubungan Permainan Outbound dengan Perkembangan Sosial Anak di Taman Kanak-kanak Kecamatan Padangsidimpuan Utara", maka metode penelitian yang dipakai adalah penelitian kuantitatif dengan metode korelasional. Populasi dalam penelitian ini adalah guru 
kelas Taman Kanak-kanak Kecamatan Padangsidimpuan Utara yang berjumlah 75 orang guru.

Sampel pada penelitian ini menggunakan Cluster Sampling dimana teknik ini digunakan untuk menentukan sampel bila obyek yang akan diteliti atau sumber data sangat luas namun mengenai penetapan besar kecilnya sampel tidaklah ada suatu ketetapan mutlak (Sugiyono,2018:135). Berdasarkan cara di atas, yang dijadikan sampel pada penelitian ini adalah hanya guru kelas terbanyak yang ada di Taman Kanak-kanak Kecamatan Padangsidimpuan Utara yang tempatnya dekat dengan peneliti (daerah domisili) yang berjumlah 36 orang guru kelas.

Sugiyono (2018: 166) instrumen penelitian adalah suatu alat yang digunakan mengukur fenomena alam maupun sosial yang diamati. Bentuk dari instrument penelitian ini adalah menggunakan angket/pernyataan dengan skala guttman dalam bentuk checklist. Dalam penilaian setiap pernyataan dalam instrumen penelitian ini hanya disediakan 2 jawaban dengan kriteria penilaian (Setuju) skor 1 , dan (Tidak Setuju) skor 0.

Teknik yang digunakan peneliti dalam pengumpulan data ini adalah menggunakan Angket. Dimana angket tersebut dibagikan kepada guru-guru kelas Taman Kanak-kanak Kecamatan Padangsidimpuan Utara yang dijadikan sampel.

Teknik analisis data adalah proses penelitian yang sangat sukar dilakukan, karena membutuhkan kerja keras, fikiran yang kreatif, dan kemampuan pengetahuan yang tinggi (Sugiyono, 2010). Tekhnik analisis data yang digunakan dalam penelitian ini adalah menggunakan metode deskriptif (temuan umum dan temuan khusus), analisis univariat, dan analisis bivariat dengan menggunakan program SPSS versi 26 dan SPSS versi 23.

\section{Hasil dan Pembahasan}

Penelitian ini dilaksanakan di beberapa sekolah Taman Kanak-kanak Kecamatan Padangsidimpuan Utara. Penelitian ini dilaksanakan pada bulan Agustus hingga bulan September 2021. Pengumpulan data dilakukan pada lima sekolah Taman Kanak-kanak, yaitu di Taman Kanak-kanak Aisyiyah Bustanul Athfal I (ABA I), Taman Kanak-kanak Al-Faiz, Taman Kanak-kanak Haholongan, Taman Kanakkanak Sariputra, dan Taman Kanak-kanak Islam Terpadu Nurul Fikri (TK IT Nurul Fikri). Pada penelitian ini sampel yang digunakan sebanyak 36 orang guru kelas. Data yang diperoleh tersebut berasal dari angket skala Guttman yang menggunakan 12 soal instrumen penelitian, dengan alternatif kriteria penilaian instrumen yakni jawaban Setuju bernilai (1) dan jawaban Tidak Setuju bernilai (0).

Kegiatan penelitian yang dilakukan di Taman Kanak-kanak Kecamatan Padangsidimpuan Utara adalah dengan membagikan lembaran angket ke Guru-guru 
kelas yang ada di Taman Kanak-kanak tersebut sesuai dengan jumlah guru kelas yang ada. Berikut adalah data hasil penelitian yang dilakukan di taman Kanak-kanak Kecamatan Padangsidimpuan Utara.

Tabel Data Hasil Penelitian di Taman Kanak-kanak Kecamatan Padangsidimpuan Utara

\begin{tabular}{|c|c|c|c|}
\hline \multirow[t]{2}{*}{ No. } & \multirow[t]{2}{*}{ Item Pernyataan } & \multicolumn{2}{|c|}{ Hasil jawaban } \\
\hline & & Setuju & Tidak Setuju \\
\hline 1. & $\begin{array}{l}\text { Permainan outbound yang dirancang } \\
\text { dilakukan secara berkelompok. }\end{array}$ & 26 orang & 10 orang \\
\hline 2. & $\begin{array}{l}\text { Permainan outbound yang disetting } \\
\text { meningkatkan kemampuan } \\
\text { bersosialisasi anak dengan temannya. }\end{array}$ & 36 orang & 0 \\
\hline 3. & $\begin{array}{l}\text { Permainan outbound yang disetting } \\
\text { melatih ketahanan mental dan } \\
\text { pengendalian diri anak serta timnya. }\end{array}$ & 36 orang & 0 \\
\hline 4. & $\begin{array}{l}\text { Permainan outbound yang dirancang } \\
\text { melibatkan antara satu anak dengan } \\
\text { anak yang lainnya. }\end{array}$ & 36 orang & 0 \\
\hline 5. & $\begin{array}{l}\text { Permainan outbound yang disetting } \\
\text { melatih kekompakan anak bersama } \\
\text { dengan timnya. }\end{array}$ & 36 orang & 0 \\
\hline 6. & $\begin{array}{l}\text { Permainan outbound yang disetting } \\
\text { meningkatkan sifat tolong-menolong } \\
\text { anak dengan temannya. }\end{array}$ & 31 orang & 5 \\
\hline 7. & $\begin{array}{l}\text { Permainan outbound yang dirancang } \\
\text { meningkatkan kerjasama anak. }\end{array}$ & 36 orang & 0 \\
\hline 8 & $\begin{array}{l}\text { Permainan outbound yang disetting } \\
\text { meningkatkan komunikasi/ interaksi } \\
\text { anak dengan temannya. }\end{array}$ & 36 orang & 0 \\
\hline 9. & $\begin{array}{l}\text { Permainan outbound yang disetting } \\
\text { meningkatkan kemampuan anak } \\
\text { mengenal diri dan orang lain }\end{array}$ & 36 orang & 0 \\
\hline
\end{tabular}




\begin{tabular}{|c|l|c|c|}
\hline 10. & $\begin{array}{l}\text { Permainan outbound yang dirancang } \\
\text { melatih kemampuan empati anak } \\
\text { terhadap temannya yang lain. }\end{array}$ & 36 orang \\
\hline 11. & $\begin{array}{l}\text { Permainan outbound melatih } \\
\text { kemampuan simpati anak terhadap } \\
\text { temannya yang lain. }\end{array}$ & 36 orang & 0 \\
\hline 12. & $\begin{array}{l}\text { Permainan outbound yang dirancang } \\
\text { melatih jiwa kepemimpinan anak. }\end{array}$ & 29 orang & 22 \\
\hline & \multicolumn{1}{|l}{ Jumlah } & 410 & \\
\hline
\end{tabular}

Tabel Pedoman untuk memberikan interpretasi koefisien korelasi

\begin{tabular}{|c|c|}
\hline $\begin{array}{c}\text { Interval } \\
\text { Korelasi }\end{array}$ & Tingkat Hubungan \\
\hline $0,00-0,25$ & Sangat Lemah \\
\hline $0,26-0,45$ & Lemah \\
\hline $0,46-0,65$ & Sedang \\
\hline $0,66-0,85$ & Kuat \\
\hline $0,86-1,00$ & Sangat Kuat \\
\hline
\end{tabular}

Tabel 4.2 Data Indikator Permainan Outbound dengan Perkembangan Sosial Anak

\begin{tabular}{|c|c|c|c|c|}
\hline \multirow{2}{*}{ No. Pernyataan } & \multicolumn{2}{|c|}{ Jumlah Responden } & \multirow{2}{*}{$\begin{array}{c}\text { Tingkat } \\
\text { hubungan }\end{array}$} \\
\cline { 2 - 4 } $\begin{array}{c}\text { Setuju } \\
1,3,5,7,8,9, \\
10,11\end{array}$ & 36 & 0 & 100 & Sangat Kuat \\
\hline 6 & 31 & 5 & 86 & Sangat Kuat \\
\hline 12 & 29 & 7 & 80 & Kuat \\
\hline 1 & 26 & 10 & 72 & Kuat \\
\hline \multicolumn{3}{|c|}{ Rata-rata } & 84 & Kuat \\
\hline
\end{tabular}

Data di atas merupakan hasil dari perolehan presentasi dari masing-masing pernyataan yang ada pada indikator permainan outbound dengan perkembangan 
sosial anak. Dari data tersebut didapatkan responden yang menjawab ya/setuju dari 12 item pernyataan rata-rata sebesar 84\% dan lebihnya16\% menjawab tidak setuju.Berdasarkan hasil persentasi tersebut, dapat dilihat hubungan permainan outbound dengan perkembangan sosial anak di Taman kanak-kanak Kecamatan Padangsidimpuan Utara sebesar 85\%, sehingga dapat dikatakan permainan outbound dengan perkembangan sosial anak di Taman kanak-kanak tersebut mempunyai hubungan yang kuat.

Patmonodewo, 2003 dalam (Astuti, 2014). Perkembangan sosial merupakan kemampuan seseorang untuk berperilaku sebagaimana mestinya agar dapat diterima dalam lingkungan masyarakat. Kemampuan sosial merupakan salah satu aspek perkembangan anak yang sangat penting untuk dikembangkan. Perkembangan sosial merupakan perolehan kemampuan berperilaku yang sesuai dengan tuntutan sosial (Hurlock, 2000:250). Yusuf dalam Suryana (2016: 190) menyatakan bahwa perkembangan sosial merupakan pencapaian kematangan dalam hubungan sosial. Perkembangan sosial dapat pula diartikan sebagai proses belajar untuk menyesuaikan diri terhadap norma-norma kelompok, moral dan tradisi, meleburkan diri menjadi satu kesatuan dan saling berkomunikasi dan kerja sama.

Perkembangan sosial berhubungan dengan perilaku anak dalam menyesuaikan diri dengan aturan-aturan yang ada dalam masyarakat. Perkembangan perilaku sosial anak ditandai dengan adanya minat terhadap aktivitas teman-teman dan meningkatkan keinginan yang kuat untuk diterima sebagai anggota suatu kelompok, dan tidak puas bila tidak bersama temantemannya (Mayar, 2013:460).

Helm \& Turner (1983:225) dalam Susanto (2017:28), pola perilaku sosial anak dapat dilihat dari empat dimensi sebagai berikut: (1) Anak dapat kerja sama (cooperating) dengan teman, (2) Anak mampu menghargai (altruism) teman, baik dalam hal menghargai milik, pendapat, hasil karya teman, (3) Anak mampu berbagi (sharing) kepada teman, (4) Anak mampu membantu (helping other) orang lain.

Suryana (2016:187-189) menyatakan bahwa bentuk-bentuk tingkah laku sosial anak adalah sebagai berikut: (1) Pembangkangan (negativism), yaitu tingkah laku melawan. Antara usia 4 dan 6 tahun, sikap pembangkangan atau melawan secara fisik beralih menjadi sikap melawan secara verbal (menggunakan kata-kata); (2) Agresi (agresion), merupakan satu bentuk reaksi terhadap rasa kecewa karena tidak terpenuhi kebutuhan atau keinginannya; (3) Berselisih/bertengkar (quarreling), terjadi apabila seorang anak merasa tersinggung atau terganggu oleh sikap atau perilaku anak lainnya; (4) Menggoda (teasing), merupakan serangan mental terhadap orang lain dengan bentuk verbal (kata-kata ejekan, cemoohan), 
sehingga menimbulkan reaksi marah pada orang yang diserangnya; (5) Persaingan (rivarly), yaitu keinginan untuk melebihi orang lain dan selalu didorong oleh orang lain.; (6) Kerja sama (cooperation), yaitu sikap mau kerja sama dengan kelompok. Anak yang berusia 2 atau 3 tahun belum berkembang sikap kerja samanya, mereka masih kuat sikap "self-centered"-nya. Mulai usia 3 tahun akhir atau 4 tahun, anak sudah mulai menampakkan sikap kerja samanya dengan anak lain. Pada usia 6 atau 7 tahun sikap kerja sama ini sudah berkembang dengan lebih baik lagi. Pada usia ini anak mau bekerja kelompok dengan teman-temannya; (7) Tingkah laku berkuasa (ascendant behavior), wujud dari tingkah laku ini seperti meminta, menyuruh, dan mengancam atau memaksa orang lain untuk memenuhi kebutuhannya; (8) Mementingkan diri sendiri (selfishness), sikap egosentris dalam memenuhi keinginannya; (9) Simpati (sympathy), sikap yang mendorong individu untuk menaruh perhatian terhadap orang lain, mau mendekati atau bekerja sama dengannya.

Permainan outbound adalah permainan yang mampu mengembangkan karakter siswa anak usia dini. Muhammad (2009) dalam (Andriyani, 2017: 29), permainan outbound adalah suatu program pembelajaran di alam terbuka yang berdasar pada prinsip experiental learning (belajar melalui pengalaman langsung) yang disajikan dalam bentuk permainan, stimulasi, diskusi dan petualangan sebagai media penyampaian materi. Artinya dalam program siswa secara aktif dilibatkan dalam seluruh kegiatan yang dilakukan, dengan langsung terlibat pada aktivitas. Permainan Outbound merupakan kegiatan di alam terbuka (outdoor), melalui permainan outbound juga dapat memacu semangat belajar pada anak (Ancok, 2000:4).

Manfaat dari permainan outbound adalah untuk meningkatkan keberanian dalam bertindak maupun berpendapat. Kegiatan outbound membentuk pola pikir yang kreatif, serta meningkatkan kecerdasan emosional dan spiritual dalam berinteraksi. Kegiatan ini akan menambah pengalaman hidup anak menuju sebuah pendewasaan diri.

Teori dari Wena (2009) yaitu membagi anak kedalam beberapa kelompok sesuai dengan jenis kegiatan yang ada, sangat mempengaruhi kelancaran pembelajaran. Selain itu dapat memberi kesempatan anak untuk berbagi dan berkerja sama dengan temannya.

Menurut Susanta (2010: 7) dalam (Isbayani, dkk, 2015) menyatakan bahwa, manfaat outbound yaitu (1) melatih ketahanan mental dan pengendalian diri; (2) menumbuhkan empati; (3) melahirkan semangat kompetisi yang sehat; (4) meningkatkan jiwa kepemimpinan; (5) melihat kelemahan orang lain bukan sebagai kendala; (6) meningkatkan kemampuan mengambil keputusan dalam situasi sulit 
secara cepat dan akurat; (7) membangun rasa percaya diri; (8) meningkatkan rasa kebutuhan akan pentingnya kerja tim untuk mencapai sasaran secara optimal; (9) dapat menghilangkan jarak antara teman baru dan teman lama dan mempererat kekompakan antara teman; (10) sikap pantang menyerah dan menumbuhkan rasa percaya diri dalam diri peserta; (11) mengasah kemampuan bersosialisasi; (12) meningkatkan kemampuan mengenal diri dan orang lain.

Menurut Indriana dan Winarti (2008) mengatakan bahwa permainan outbound memberikan anak kemampuan untuk berkompetesi yang terintegrasi dengan pengetahuan tentang lingkungan dan didukung oleh pembelajaran tentang kepemimpinan, kerjasama, kemandirian, kepercayaan diri, motivasi, kreatifitas, tanggung jawab dan pemecahan masalah. Menurut Isbayani (2015) dalam (Sintia, dkk, 2019: 2) Permainan outbound adalah model pembelajaran yang dapat meningkatkan kemampuan sosial bagi anak usia dini

Dalam pengisian angket hubungan permainan outbund dengan perkembangan sosial anak peneliti meminta para guru untuk mengisi dan menjawab sesuai dengan petunjuk yang diberikan. Dari hasil yang dijawab oleh para guru Taman kanak-kanak yang ada di Kecamatan Padangsidimpuan Utara, permainan outbound yang dirancang oleh guru dapat mengembangkan perkembangan sosial anak sesuai dengan aspek sosialnya seperti dapat membentuk kelompok dan melakukan kerja sama untuk menyelesaikan permainan, menumbuhkan rasa percaya diri dan ketahanan mental dalam mengendalikan diri anak dengan timnya, dapat bersosialisasi dengan teman setim dan juga tim lainnya, dapat berinteraksi dengan teman sekitarnya, besarnya rasa simpati dan empati anak terhadap temannya, melalui permainan outbound anak dapat mengenal diri dan orang lain, meningkatnya kemampuan berinteraksi/komunikasi anak dengan teman dan lingkungan sekitarnya.

Berdasarkan hasil penelitian tersebut, dapat dikatakan bahwa permainan outbound dengan perkembangan sosial anak di Taman Kanak-kanak Kecamatan Padangsidimpuan Utara sebesar 84\% mempunyai hubungan yang kuat. Apabila permainan outbound dirancang sesuai dengan aspek perkembangan sosial anak, maka terlihat perkembangan sosial anak berkembang dengan baik saat melakukan permainan outbound. Namun apabila permainan outbound yang dirancang tidak sesuai dengan aspek perkembangan sosial anak, maka perkembangan sosial anak juga tidak berkembang dengan baik. Sehingga penelitian ini dapat membuktikan bahwa permainan outbound memiliki hubungan yang kuat dengan perkembangan sosial anak. 


\section{Simpulan}

Penelitian yang dilakukan membuktikan bahwa terdapat hubungan permainan outbound dengan perkembangan sosial anak di Taman Kanak-kanak Kecamatan Padangsidimpuan utara. Dapat dilihat dari data hasil penelitian yang dilakukan bahwa permainan outbound memiliki hubungan yang kuat terhadap perkembangan sosial anak sebesar 84\%. Apabila permainan outbound yang dirancang sesuai dengan ketentuan aspek-aspek perkembangan sosial anak, maka perkembangan sosial anak dalam permainan outbound akan terlihat.

\section{Daftar Rujukan}

Ancok, D. 2000. Outbound Management Training. Yogyakarta: UII Press. . 2004. Outbound Management Training. Yogyakarta: UII Press. 2006. Outbound Management Training. Yogyakarta: UII Press.

Andriyani, Novi. 2017. Pengaruh Permainan Outbound terhadap kemampuan kerja sama pada anak. Magelang: Universitas Muhammadiyah Magelang.

Andriyani, Novi. 2018. Pengaruh Permainan Outbound terhadap kemampuan kerja sama pada anak. Magelang: Universitas Muhammadiyah Magelang.

Astuti, Tri Yuni. 2014. Meningkatkan Kemampuan Kerjasama Melalui Permainan Menyusun Puzzle Berkelompok Di Rhaudatul Athfal Masyithoh Kantongan Kelompok A. Yogyakarta: UNY (http://eprints.uny.ac.id/14245/1/ tri. Yuni .astuti10111247038.pdf).

Indriani dan Windarti. 2008. Mengembangkan Kematangan Sosial pada Anak Melalui Outbound. Jurnal Sekolah Dasar. (Vol. 17, No. 2)

Isbayani, dkk. 2015. Penerapan Metode Outbound untuk Meningkatkan Keterampilan Sosial Emosional Anak. e-Jurnal Pendidikan Guru Pendidikan Anak Usia Dini. Universitas Pendidikan Ganesa.(No 1,Vol. 3).

Mayar, Farida. 2013. Perkembangan sosial anak usia dini sebagai bibit untuk masa depan bangsa. Jurnal Al-Ta'lim: Jilid 1 (No.6) hlm 459-462.

Mulyasa. 2014. Manajemen Paud. Bandung: PT Remaja Rosdakarya.

Sintia, dkk. 2019. Meningkatkan Kemampuan Sosial Anak Usia Dini dengan Model Outbound. Jurnal Care: Children Advisory Research and Education 6 (2).

Sugiyono. 2010. Metode Penelitian Kuantitatif. Bandung: Alfabeta 2018. Metode Penelitian Kuantitatif. Bandung: Alfabeta

Susanto, Ahmad. 2017. Pendidikan Anak Usia Dini Konsep Dan Teori. Jakarta: Bumi Aksara.

Wena, Made. 2009. Strategi Pembelajaran Inovatif Kontemporer Suatu Tinjauan Konseptual Operasional. Jakarta: Bumi Aksara 
Rahmy Latifah, Serli Marlina

Yusuf, Syamsu. 2014. Teori Psikologi Perkembangan Erik H. Erikson Dan Manfaatnya Bagi Tugas Pendidikan Kristen Dewasa Ini. Kurios: Jurnal Teologi Dan Pendidikan Agama Kristen. (No. 2, Vol. 2) 